\title{
Effect of Sodium Alginates Rich in Guluronic and Mannuronic Acids on Cholesterol Levels and Digestive Organs of High-cholesterol-fed Rats
}

\author{
Takeshi Suzuki, ${ }^{* 1}$ Kiyonori Nakai, ${ }^{* 1,2}$ Yumiko Yoshie, ${ }^{* 1}$ \\ Takaaki Shirai, ${ }^{* 1}$ and Toshiyuki Hirano ${ }^{* 1}$ \\ (Received November 19, 1992)
}

\begin{abstract}
Comparative effects of sodium alginates rich in guluronic and mannuronic acids on cholesterol levels and digestive organs were evaluated in rats fed with diets containing both alginates and cholesterol. Food intake of rats fed on diets with alginate was significantly smaller than that without alginate. Animals on guluronic acid-rich alginate had a significantly lower food intake and grew more poorly than did those on mannuronic acid-rich alginate. Both alginate diets produced a significantly lighter liver and spleen, but a heavier cecum, small intestine, and large intestine compared to diets without alginate. Alginates protected to become a fatty liver in rats which took a large quantity of cholesterol. Dramatic reductions in liver cholesterol were found in rats fed with each alginate, and cholesterol accumulation was significantly low in mannuronic acid-rich alginate. In addition, both alginates were shown to have a high potential for lowering the serum cholesterol level, but the HDL-cholesterol levels were statistically similar. The main reason for the lowering of the serum cholesterol level seemed to be the lower amount of ingested cholesterol. The fatty acid composition of liver fat in rats fed with alginates was nearly the same as that without cholesterol.
\end{abstract}

Dietary fiber can be defined as those constituents of foods that are resistant to digestion by the secretions of the human gastrointestinal tract. ${ }^{12}$ Dietary fiber has been reported to have several physiological effects, depending upon the physical and chemical properties of the individual fiber sources. ${ }^{1)}$ These effects include improving large bowel function, increasing fecal bulk, and decreasing nutrient availability, levels of plasma cholesterol, and glycemic responses to a meal. Among dietary fibers of land plants, cellulose, some hemicelluloses, and lignin are regarded as insoluble, whereas pectins, gums, mucilages, and other types of hemicellulose are regarded as soluble.2

The consumption of diets high in complex carbohydrates such as dietary fiber was reported to reduce blood cholesterol levels as far back as 1961.3) Both human and animal studies have generally confirmed a potential hypocholesterolemic effect of water soluble dietary fiber ingestion, but insoluble fibers have no effect on serum cholesterol levels. A reduction in total blood cholesterol is not necessary beneficial if this reduction is in cholesterol associated with high density lipoprotein (HDL), while a decrease in the blood cholesterol associated with low density lipoprotein (LDL) is believed to reduce the risk of heart disease. ${ }^{4}$

Seaweeds, which have been eaten by the Japanese since ancient times, are known to contain a large quantity of dietary fiber. Alginic acid is distributed only in brown algae, while sodium alginate, soluble fiber, is generally used for food additives. Several studies ${ }^{(-\theta)}$ have investigated the effects of alginate diet on serum cholesterol levels in rats, and have indicated the hypocholesterolemic effect of alginates. However, they have only measured the total cholesterol in serum, and have not analyzed HDL or LDL cholesterol. On the other hand, some reports have shown that alginate does not attenuate the cholesterolemic effect of diet cholesterol. ${ }^{10,113}$

Alginic acid consists of two uronic acids, i.e. guluronic and mannuronic acids, and the properties of alginic acid depends on the contents of each acid. Therefore, this study focuses on the effects of alginates rich in guluronic or mannuronic

*1 Department of Food Science and Technology, Tokyo University of Fisheries, Konan, Minato, Tokyo 108, Japan（跲木 健，中井清典，吉江由美子，白井隆明，平野敏行：東京水産大学食品生産学科).

*2 Current address: Central Research Laboratory, Nippon Suisan Kaisha Ltd., Kitano, Hachioji, Tokyo 192, Japan (中井清典: 日本水産株式会社中央研究所). 
Table 1. Composition of diets

\begin{tabular}{|c|c|c|c|c|}
\hline \multirow{2}{*}{ Constituents } & \multicolumn{4}{|c|}{ Diet*1 } \\
\hline & $\mathrm{B}$ & $\mathrm{C}$ & $\mathrm{C}+\mathrm{G}$ & $\mathrm{C}+\mathrm{M}$ \\
\hline Casein & 220 & 220 & 220 & 220 \\
\hline Lard & 80 & 80 & 80 & 80 \\
\hline Corn oil & 20 & 20 & 20 & 20 \\
\hline Mineral mixture* & 40 & 40 & 40 & 40 \\
\hline Vitamin mixture*s & 8.5 & 8.5 & 8.5 & 8.5 \\
\hline Choline chloride & 2 & 2 & 2 & 2 \\
\hline Cholesterol & 0 & 10 & 10 & 10 \\
\hline Sodium cholate & 0 & 2.5 & 2.5 & 2.5 \\
\hline Sodium alginate-G*4 & 0 & 0 & 50 & 0 \\
\hline Sodium alginate- $\mathrm{M}^{*}$ & 0 & 0 & 0 & 50 \\
\hline Sucrose & 629.5 & 617 & 567 & 567 \\
\hline
\end{tabular}

*1 B, basal; $C$, cholesterol; $C+G$, cholesterol +alginate- $G$; and $C+M$, cholesterol + alginate-M.

*2 AIN mineral mixture 76.12)

Supplied per $\mathrm{kg}$ of mixture: $\mathrm{CaHPO}_{4} 500 \mathrm{~g} ; \mathrm{NaCl}, 74 \mathrm{~g} ; \mathrm{K}_{3} \mathrm{C}_{6} \mathrm{H}_{5} \mathrm{O}_{7} \cdot \mathrm{H}_{2} \mathrm{O}, 220 \mathrm{~g} ; \mathrm{K}_{2} \mathrm{SO}_{4}, 52 \mathrm{~g} ; \mathrm{MgO}_{2} 24 \mathrm{~g} ; \mathrm{MnCO}_{3} \cdot \mathrm{nH}_{2} \mathrm{O}$, $3.5 \mathrm{~g} ; \mathrm{FeC}_{6} \mathrm{H}_{5} \mathrm{O}_{7} \cdot \mathrm{nH}_{2} \mathrm{O}, 6 \mathrm{~g} ; \mathrm{ZnCO}_{2}, 1.6 \mathrm{~g} ; \mathrm{CuCO}_{3} \cdot \mathrm{Cu}(\mathrm{OH})_{2} \cdot \mathrm{H}_{2} \mathrm{O}, 0.3 \mathrm{~g} ; \mathrm{KlO}_{3}, 0.01 \mathrm{~g} ; \mathrm{Na}_{2} \mathrm{SeO}_{8} \cdot 5 \mathrm{H}_{2} \mathrm{O}, 0.01 \mathrm{~g} ;$ and $\mathrm{CrK}\left(\mathrm{SO}_{4}\right)_{2} \cdot 12 \mathrm{H}_{2} \mathrm{O}, 0.55 \mathrm{~g}$.

*3 AIN vitamin mixture 76.12)

Supplied per $\mathrm{kg}$ of mixture: thiamine $\cdot \mathrm{HCl}, 0.6 \mathrm{~g}$; riboflavin, $0.6 \mathrm{~g}$; pyridoxine $\cdot \mathrm{HCl}, 0.7 \mathrm{~g}$; nicotinic acid, $3 \mathrm{~g}$; calcium pantothenate, $1.6 \mathrm{~g}$; folic acid, $0.2 \mathrm{~g}$; biotin, $20 \mathrm{mg}$; cyanocobalamin, I mg; retinol acetate, $400,000 \mathrm{IU}$; cholecalicferol, $100,000 \mathrm{IU}$; DL- $\alpha$-tocopherol, $5,000 \mathrm{IU}$; and menadione, $5 \mathrm{mg}$.

*4 Rich in guluronic acid.

*5 Rich in manntronic acid.

acids on cholesterol levels and fatty acid composition in rats. We have aslo examined the growth and digestive organs of rats fed with diets containing these alginates.

\section{Meterials and Methods}

\section{Animals and Diets}

Male, 5-week-old Wister rats (Cler Japan Inc., Tokyo) were provided with a stock diet (CE-2, Cler Japan Inc., Tokyo) for 6 days to acclimate to laboratory conditions. They were housed individually in stainless steel, wire mesh-bottomed cages in a temperature-controlled room (21$23^{\circ} \mathrm{C}$ ) provided with a $12 \mathrm{~h}$ daily light-dark cycle. The rats were randomly distributed into four groups of six animals each. The composition of the purified diets, based on the American Institute of Nutrition, ${ }^{12}$ is presented in Table 1. All reagents are analytical grade. Sodium alginates rich in guluronic acid (molar ratio of mannuronic and guluronic acids, $M / G=0.53$ ) and mannuronic acid $(M / G=2.4)$ were donated by Kimitsu Chemical Industries, Tokyo. The ratio of guluronic and mannuronic acids was determined by the method of Haug et al.13) The cholesterol diet (C) was made by diluting the basal diet (B) to contain cholesterol and sodium cholate, ${ }^{11)}$ and the cholesterol plus guluronic acid rich alginate diet $(\mathrm{C}+\mathrm{G})$ and the cholesterol plus mannuronic acid rich alginate diet $(C+M)$ were made by dilution of the cholesterol diet (C) with sodium alginate rich in guluronic acid and mannuronic acid, respectively. Food and water were allowed ad libitum for 12 days. Body weight and food consumption were measured daily, and feces were collected on the last three days of the feeding period.

\section{Serum and Digestive Organs}

Each animal was anesthetized with ether and the abdominal cavity was opened. Blood was drawn from the main artery and collected in a tube (VT-AS109, Terumo Co., Tokyo). The blood was kept on ice until centrifuged at 10,000 $\times$ $\mathrm{g}$ for $10 \mathrm{~min}$. The serum was pipetted into another tube and frozen until analysis. The digestive organs were quickly removed and weighed. The contents of cecum and large intestine were brought together.

\section{Cholesterol}

Total and HDL cholesterols in serum were assayed by a cholesterol oxidase-phenol method and a heparin-manganese method, using Cholesterol-C. Test Wako and HDL-Cholesterol Test Wako (Wako Pure Chemical Industries, Ltd., Osaka), respectively. LDL cholesterol was 
calculated from the total and HDL cholesterols. The arteriosclerotic index is the ratio of LDL and HDL cholesterols. ${ }^{44}$

Lipids were extracted from the liver using the method of Bligh and Dyer, ${ }^{15)}$ and from freezedried feces and contents of cecum and large intestine with hot ethanol. ${ }^{10}$ ) Total cholesterol in the liver, feces, and contents of cecum and large intestine were assayed by the same method as described above. Apparent accumulation was expressed as a percentage of total liver cholesterol to ingested cholesterol. ${ }^{17}$ )

\section{Fatty Acids}

The extracted liver lipids were transmethylated using boron trifluoride-methanol (Tokyo Chemical Industry Co., Tokyo) and fatty acid methyl esters were subjected to gas chromatography (Hitachi 164 gas chromatograph, Hitachi Ltd., Tokyo), using a $3 \mathrm{~mm} \times 3 \mathrm{~m}$ column packed with 80-100 mesh Uniport B coated with 15\% DEGS at $197^{\circ} \mathrm{C}$; carrier gas, $\mathrm{N}_{2}$, flow rate $30 \mathrm{~m} / \mathrm{min}$; detector, FID.

\section{Statistical Analysis}

Values are presented as the mean and standard error. Significant differences between groups were determined by the Student's $t$-test or Welch test. Results were considered statistically significant at $p<0.05$ or lower.

\section{Results and Discussion}

\section{Food Intake and Growth}

Food intake and body weights of rats during the experimental periods are shown in Figs. 1 and 2, respectively. Animals on diets containing alginate, especially diet $C+G$, ate a smaller weight of food than those on diets $B$ and $C$ during the first three days of feeding. At the conclusion of the 12-day feeding period, total food intakes of rats ranged from $116.1 \pm 2.3$ (diet $C+G$ ) to 184.2 $\pm 7.2 \mathrm{~g}$ (diet B), and these differences were statistically significant between diets $C$ (and $B$ ), $\mathbf{C}+\mathbf{M}$, and $\mathbf{C}+\mathbf{G}$.

Initial weights of the four rat groups were equal (raning from $121.8 \pm 2.5$ to $122.2 \pm 2.6 \mathrm{~g}$ ), but rats fed on diets with alginate, especially diet $\mathbf{C}+\mathbf{G}$, had significantly less weight at the beginning of the experiment (Fig. 2). Weight gain in the alginate group (diets $\mathrm{C}+\mathrm{G}$ and $\mathrm{C}+\mathrm{M}$ ) recovered after 3 days. The average body weight of rats fed on diets with alginate increased

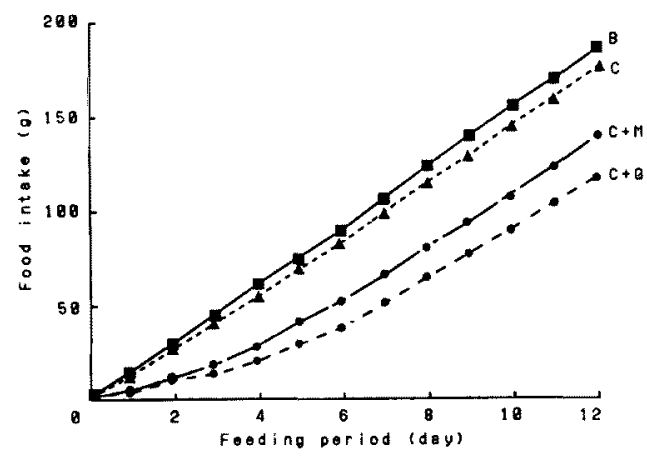

Fig. 1. Food intake of rats.

Refer to Table 1 for symbols to diets.

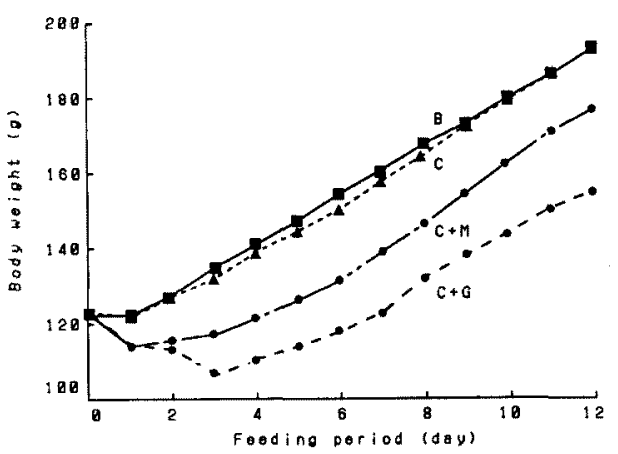

Fig. 2. Body weight of rats.

Refer to Table 1 for symbols to diets.

to $154.0 \pm 3.2$ (diet $\mathrm{C}+\mathrm{G}$ ) and $175.6 \pm 1.2 \mathrm{~g}$ (diet $\mathrm{C}+\mathrm{M}$ ) on the final day, while those fed without alginate increased to $192.6 \pm 3.9$ (diet B) and $192.2 \pm 5.3 \mathrm{~g}$ (diet $\mathrm{C}$ ), i.e. $16-39 \mathrm{~g}$ higher than the alginate group. Food efficiency of diet $\mathrm{C}+\mathrm{G}(27.3 \pm 1.8 \%)$, calculated as weight gain/ food intake, was significantly low in comparison with that of diets $\mathrm{C}(40.3 \pm 0.5 \%)$ or $\mathrm{C}+\mathrm{M}$ $(39.3 \pm 0.6 \%$ ). In this study, animals on guluronic acid-rich alginate had a significantly lower food intake and grew more poorly than did those on mannuronic acid-rich alginate.

According to the experiment by Tsuji et al.,5) sodium alginate added to diets at $5 \%$ retarded the food intake and growth of rats, but Tsuji et al ${ }^{8)}$ stated that alginic acid and a mixture of calcium alginate and sodium alginate, which are insoluble carbohydrates, did not have these effects. Sodium alginate rich in guluronic acid is known to be more soluble in water than rich in mannuronic acid. Therefore the solubility seemed 
Table 2. Weights of digestive organs in rats

\begin{tabular}{|c|c|c|c|c|}
\hline & \multicolumn{4}{|c|}{ Diets } \\
\hline & B & $\mathrm{C}$ & $\mathrm{C}+\mathrm{G}$ & $\mathrm{C}+\mathrm{M}$ \\
\hline Liver $(\mathrm{g})$ & $12.0 \pm 0.40^{\mathrm{a}}$ & $14.0 \pm 0.40^{\mathrm{b}}$ & $9.60 \pm 0.30^{\circ}$ & $11.2 \pm 0.30^{\mathrm{s}}$ \\
\hline$\%$ of body weight & $6.23 \pm 0.23^{\mathrm{a}}$ & $7.31 \pm 0.08^{b}$ & $6.22 \pm 0.15^{a}$ & $6.40 \pm 0.17^{a}$ \\
\hline Spleen $(\mathrm{g})$ & $0.67 \pm 0.03^{\mathrm{a}}$ & $0.71 \pm 0.05^{a}$ & $0.50 \pm 0.01^{\mathrm{b}}$ & $0.63 \pm 0.02^{\mathrm{a}}$ \\
\hline$\%$ of body weight & $0.35 \pm 0.02^{\mathrm{s}}$ & $0.37 \pm 0.02^{\mathrm{a}}$ & $0.33 \pm 0.01^{\mathrm{a}}$ & $0.36 \pm 0.01^{\mathrm{a}}$ \\
\hline Cecum $(\mathrm{g})$ & $2.38 \pm 0.17^{\mathrm{a}}$ & $2.00 \pm 0.17^{\mathrm{a}}$ & $3.11 \pm 0.19^{\mathrm{b}}$ & $3.13 \pm 0.10^{\mathrm{b}}$ \\
\hline$\%$ of body weight & $1.23 \pm 0.07^{\mathrm{a}}$ & $1.04 \pm 0.10^{\mathrm{a}}$ & $2.02 \pm 0.12^{\mathrm{b}}$ & $1.78 \pm 0.06^{\mathrm{b}}$ \\
\hline Small intestine $(\mathrm{g})$ & $7.12 \pm 0.64^{\mathrm{a}}$ & $6.56 \pm 0.37^{\mathrm{a}}$ & $10.0 \pm 0.41^{b}$ & $10.9 \pm 0.39^{\mathrm{b}}$ \\
\hline$\%$ of body weight & $3.69 \pm 0.31^{\mathrm{a}}$ & $3.40 \pm 0.11^{\approx}$ & $6.48 \pm 0.23^{b}$ & $6.19 \pm 0.20^{\mathrm{b}}$ \\
\hline Large intestine (g) & $1.58 \pm 0.09^{\mathrm{a}}$ & $1.31 \pm 0.09^{a}$ & $2.58 \pm 0.26^{\mathrm{b}}$ & $2.90 \pm 0.26^{\mathrm{b}}$ \\
\hline$\%$ of body weight & $0.82 \pm 0.03^{a}$ & $0.68 \pm 0.04^{a}$ & $1.67 \pm 0.15^{b}$ & $1.66 \pm 0.60^{b}$ \\
\hline
\end{tabular}

Refer to Table 1 for symbols of the diets.

Horizontal values not sharing the same superscript letters are significantly different $(p<0.05)$.

to be a leading cause for retardation of food intake of alginate diets.

\section{Digestive Organs}

Wet weights of liver, spleen, cecum, small intestine, and large intestine including their contents are presented in Table 2, while the percentage of the weights of these digestive organs to body weights is also calculated. The effects of sodium alginate on the weights of digestive organs were clearly shown in this experiment; when compared with $\operatorname{diet} C$, diets $C+G$ and $C+M$ produced significantly lighter liver and spleen (except for the spleen of $\operatorname{diet} \mathbf{C}+\mathbf{M}$ ), but significantly heavier cecum, small intestine, and large intestine with contents. The precentage of the weights of these digestive organs to body weight was also similar to those excluding the spleen. These results indicated that rats poorly digested and absorbed alginate in the upper digestive tract, and alginate remained in the lower digestive tract. Of the rats fed with alginates, diet $\mathrm{C}+\mathrm{G}$ lessened the weights of the liver and spleen more than diet $\mathrm{C}+\mathrm{M}$. However there was no significant difference in the weights of cecum, small intestine, and large intestine between guluronic acid and mannuronic acid rich alginates.

The liver color of the rats given diet $\mathbf{C}$ was very light when compared to those given other diets, and this color and weight of the liver indicated it to be fatty. However the liver color of rats fed with diets $C+G$ and $C+M$ was brown, nearly the same as that of rats without cholesterol (diet B). From these results diets with $5 \%$ alginate protected to become a fatty liver in rats which took a large quantity of cholesterol.
Ikegami et al. ${ }^{18}$ ) reported that rats fed with sodium alginate had significantly increased weights of digestive organs such as stomach, pancreas, cecum, and small and large intestines compared to control rats, whereas alginic acid and calcium alginate, which are insoluble polysaccharides, were almost inactive. They stated that viscosityproducing fibers were associated with significant adaptive changes in the digestive system. According to the research on sodium alginates of different viscosity, high viscous alginate $(9.90$ dyn $\cdot \mathrm{s} \cdot \mathrm{cm}^{-2}: 990 \mathrm{cP}$ ) clearly reduced the food intake, weight gain, and liver weight of rats more than low viscous alginate (1.49 dyn's. $\mathrm{cm}^{-2}: 149 \mathrm{cP}$ ), but there was no difference in cecum weight. ${ }^{9)}$ Since, in this experiment, the viscosity of sodium alginates rich in guluronic and mannuronic acids at a concentration of $1 \%$ was 3.00 and $2.50 \mathrm{dyn} \cdot \mathrm{s} \cdot \mathrm{cm}^{-2}(250 \mathrm{cP})$, respectively, the viscosity did not influence the digestive organs.

\section{Cholesterol}

Cholesterol levels in serum, liver, contents of intestine, and feces of rats are summarized in Table 3. Diet $C+G(2150 \pm 90 \mathrm{mg} / \mathrm{m} l)$ significantly lowered the serum cholesterol concentrations as compared with diet $\mathrm{C}(2790 \pm 40 \mathrm{mg} / \mathrm{m} l)$, but diet $C+M(2510 \pm 180 \mathrm{mg} / \mathrm{m} l)$ slightly reduced it. Rats fed with alginates (diet $\mathrm{C}+\mathrm{G}, 1160 \pm$ $20 \mathrm{mg}$; diet $C+M, 1370 \pm 10 \mathrm{mg}$ ) ingested a significantly smaller amount of cholesterol than rats without alginates (diet C, $1740 \pm 60 \mathrm{mg}$ ).

There were slight differences in the serum HDL-cholesterol in concentrations among the diets. LDL is known to carry cholesterol from the liver to the tissues. In the case of rats, the 
Table 3. Cholesterol levels in serum, liver, contents of intestine, and feces of rats

(Mean \pm S.E.)

\begin{tabular}{lccc}
\hline & & Diets & \\
& $\mathrm{C}$ & $\mathrm{C}+\mathrm{G}$ & $\mathrm{C}+\mathrm{M}$ \\
\hline Ingested (mg/rat) [1] & $1740 \pm 60^{\mathrm{a}}$ & $1160 \pm 20^{\mathrm{b}}$ & $1370 \pm 10^{\mathrm{c}}$ \\
Serum (mg/ml) [2] & $2790 \pm 40^{\mathrm{a}}$ & $2150 \pm 90^{\mathrm{b}}$ & $2510 \pm 180^{\mathrm{a}} \mathrm{b}^{\mathrm{b}}$ \\
Serum HDL (mg/m/) [3] & $393 \pm 23^{\mathrm{a}}$ & $356 \pm 18^{\mathrm{a}}$ & $325 \pm 19^{\mathrm{a}}$ \\
Arteriosclerotic index & $6.2 \pm 0.6^{\mathrm{a}, \mathrm{b}}$ & $5.1 \pm 0.3^{\mathrm{a}}$ & $6.9 \pm 0.7^{\mathrm{b}}$ \\
Liver (mg/g) & $36.9 \pm 2.3^{\mathrm{a}}$ & $30.6 \pm 1.5^{\mathrm{a}} \mathrm{b}$ & $28.8 \pm 1.0^{\mathrm{b}}$ \\
$\quad$ (mg/liver) [4] & $516 \pm 22^{\mathrm{a}}$ & $298 \pm 12^{\mathrm{b}}$ & $317 \pm 12^{\mathrm{b}}$ \\
Accumulation*2 (\%) & $29.7 \pm 1.6^{\mathrm{a}}$ & $25.2 \pm 1.1^{\mathrm{a}}, \mathrm{b}$ & $22.8 \pm 0.8^{\mathrm{b}}$ \\
Contents of & & & \\
$\quad$ intestine (mg/rat) [5] & $26.7 \pm 4.1^{\mathrm{a}}$ & $12.1 \pm 1.5^{\mathrm{b}}$ & $15.1 \pm 0.7^{\mathrm{a}, \mathrm{b}}$ \\
Feces (mg/rat daily) [6] & $36.8 \pm 4.7^{\mathrm{a}}$ & $37.4 \pm 2.9^{\mathrm{a}}$ & $41.9 \pm 2.8^{\mathrm{a}}$ \\
Undigested*3 (mg/rat daily) & $63.5 \pm 2.4^{\mathrm{a}}$ & $49.5 \pm 3.7^{\mathrm{b}}$ & $57.0 \pm 3.4^{\mathrm{a}, \mathrm{b}}$ \\
Absorption*4 (\%) & $60.2 \pm 1.9^{\mathrm{a}}$ & $67.9 \pm 3.3^{\mathrm{a}}$ & $66.1 \pm 1.5^{\mathrm{a}}$
\end{tabular}

Refer to Table 1 for symbols of the diets.

Horizontal values not sharing the same superscript letters are significantly different $(p<0.05)$.

*1 Serum LDL-cholesterol/[3].

Serum LDL-cholesterol $=[2]-[3]$,

*2 ([4]/[1] $\times 100$.

*3 $[5]+[6]$.

*4 $\{1-([5]+[6]-$ Endogeneous cholesterol $) /[1]\} \times 100$.

Endogeneous cholesterol $=5.3(\mathrm{mg} / \mathrm{rat}$ daily).

serum LDL-cholesterol level was lower than that of rabbits or human beings, since VLDL (very low density lipoprotein)-cholesterol was broken down in the liver. ${ }^{19}$ ) The higher level of LDL, the greater the risk of atherosclerosis. HDL carries cholesterol from the tissues, including the lining of the arteries, back to the liver and reduces the risk of heart disease. Therefore, an arteriosclerotic index ${ }^{14}$ ) was calculated from the ratio of LDL-cholesterol to HDL-cholesterol in serum. Guluronic acid-rich alginate (diet $\mathrm{C}+\mathrm{G}, 5.0 \pm 0.3$ ) produced a significantly lower arteriosclerotic index than mannuronic acid-rich alginate (diet $C+M, 6.7 \pm 0.7$ ), but no significant difference was found between these alginate diets $(\mathrm{C}+\mathrm{G}$ and $\mathrm{C}+\mathrm{M})$ and $\operatorname{diet} \mathrm{C}(6.1 \pm 0.6)$.

Rats fed with alginate (diets $C+G, 298 \pm 12 \mathrm{mg}$ and $C+M, 317 \pm 12 \mathrm{mg}$ ) showed a significant decrease in liver cholesterol when compared to those fed with diet $\mathrm{C}(516 \pm 22 \mathrm{mg})$. Also liver cholesterol concentrations in rats fed with alginate especially rich in mannuronic acid $(28.8 \pm 1.0 \mathrm{mg} / \mathrm{g})$ were significantly reduced (diets $\mathrm{C}+\mathrm{G}, 36.9 \pm 2.3 \mathrm{mg} / \mathrm{g}$ ). Cholesterol accumlation in the liver, calculated from liver cholesterol and ingested cholesterol, ${ }^{17}$ ) was significantly lower in the alginate diet (especially diet $\mathrm{C}+\mathrm{M}$, $22.8 \pm 0.8 \%)$ than in diet $\mathrm{C}(29.7 \pm 1.6 \%)$.

Cholesterol levels of the contents of the intestine in rats given diets $\mathrm{C}, \mathrm{C}+\mathrm{G}$, and $\mathrm{C}+\mathrm{M}$ were $26.7 \pm 4.1,12.1 \pm 1.5$, and $15.1 \pm 0.7 \mathrm{mg}$, respectively. Diet $\mathrm{C}+\mathrm{G}$ showed a significantly lower level than diet $C$. The increase in total cholesterol in feces was not clearly found in either of diets $C+G$ and $C+M$ compared to diet $C$, although the weight of the feces increased with alginate feeding. Undigested cholesterol, ${ }^{18)}$ the sum of cholesterol in feces and contents of the intestine, in rats fed with diet $\mathrm{C}+\mathrm{G}$ was significantly smaller than that with $\operatorname{diet} \mathrm{C}$. However, the absorption of cholesterol ${ }^{18)}$ in all groups fed with their respective diets was statistically similar, and endogenous cholesterol obtained from basal diet rats was $5.3 \mathrm{mg} / \mathrm{rat}$ daily. In the case of rats fed with rice bran hemicellulose, a large amount of cholesterol was accumulated in the large intestine. ${ }^{10)}$

Liver is known to be the principal organ of cholesterol metabolism, and the regulation of the serum cholesterol level, mentioned above, is dependent not only upon the rate of synthesis but also upon the rate of degradation and excretion of cholesterol in the liver. Some cholesterol is excreted in the bile, in which it is found in conjugated bile acids such as taurocholic and glycocholic acids, and is reabsorbed from the intestine. The ability of the liver to excrete cholesterol depends ultimately upon the efficiency 
with which it can remove cholesterol from the circulation. Thus, the regulation of the serum cholesterol level is the net result of cholesterol synthesis, cholesterol intake from a diet, and subsequent oxidation and excretion from the body. ${ }^{20)}$ Factors that tend to lower serum cholesterol therefore may operate at any one of these points.

Ito and Tsuchiya ${ }^{e)}$ reported that sodium alginates which were 417 and 226 in the number average degree of poymerization were effective in lowering plasma cholesterol levels in rats, while another insignificant sample was 13 in the degree of polymerization. In this study, as mentioned above, there was no notable difference in the molecular weight of sodium alginates rich in guluronic acid and mannuronic acid, since the viscosity of both sodium alginates was nearly the same. Tsuji et $a .^{.5)}$ and Tsuji et al. ${ }^{8)}$ investigated the influence of alginic acid, sodium alginate, and a mixture of sodium and calcium alginates on serum and liver cholesterol of rats, and found that alginates lowered the serum and liver cholesterol levels. Tsuji et $a l^{83}$ stated that alginates reduced the amount of ingested cholesterol, and also that no significant inter-group differences were observed in respect to the accumulation of cholesterol in liver. These results indicated that the low level of serum and liver cholesterol in the alginate diet might be due to the low amount of ingested cholesterol. However, in our study, mannuronic acid-rich alginate significantly reduced the choelsterol accumulation in liver (Table 3).

Koseki et al. ${ }^{12}$ examined cholesterol excretion by pectin in rats, and reported that the increase in total cholesterol in the feces of rats fed with pectin was much greater than that fed with the control diet. From an in vitro experiment, they suggested that the increase of cholesterol excretion into feces might be due to the entrapment by soluble dietary fiber matrix or the destruction of the micelles of cholesterol with the fiber. ${ }^{21}$ ) Cholesterol absorption in rats, however, should be compared using the isotope method.22)

From this research, dramatic reductions in liver cholesterol were found in rats fed with both alginates, and cholesterol accumulation was significantly low in alginate rich in mannuronic acid. In addition, alginate was shown to have a high potential for lowering the serum cholesterol level, though the HDL-cholesterol levels were statistically similar. The main reason for the lowering of the serum cholesterol level seemed

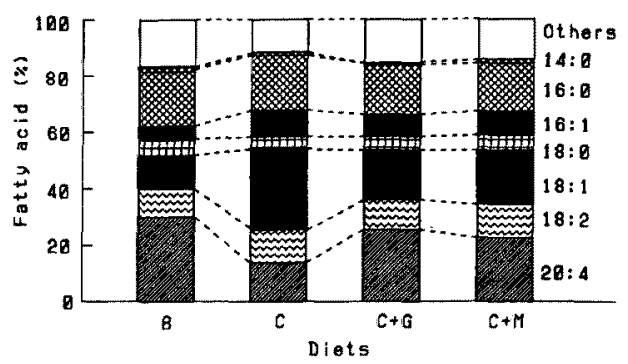

Fig. 3. Fatty acid composition of fats in rat liver. Refer to Table 1 for symbols to diets.

to be the lower amount of ingested cholesterol.

\section{Fatty Acids}

Fatty acid composition of liver fat is shown in Fig. 3 as $\mathrm{C}$ numbers. Diet $\mathrm{C}$ significantly increased $C_{18: 1}$ (palmitoleic acid) and $C_{18: 1}$ (oleic acid), and decreased $C_{20: 4}$ (arachidonic acid) in comparison with diet $B$. When alginate was fed to the rats, the primary change in fatty acid compositions occurred in $\mathrm{C}_{20: 4}$; it was significantly higher than in diet $C$, and $\mathrm{C}_{18: 0}, \mathrm{C}_{18: 1}$, and $C_{18: 1}$ were significantly lower except for $C_{18: 1}$ in diet $\mathrm{C}+\mathrm{M}$. Therefore, the pattern of fatty acid composition of rats fed with alginate diets $(C+G$ and $C+M$ ) was nearly the same as that without cholesterol (diet B). There was no significant difference in $C_{18: 0}, C_{18: 0}$, and $C_{18: 2}$ between the diets.

The increase of $C_{18: 1}$ and $C_{18: 1}$, and the decrease of $\mathrm{C}_{20: 4}$ in the liver fat of rats fed with cholesterol were also reported, but alginate could not restore these fatty acids to the level of diets without cholesterol.s2

\section{Acknowledgement}

We wish to express our gratitude to Dr. M. Ishikawa of Kimitsu Chemical Industries for supplying us with alginate.

\section{References}

1) M. L. Dreher: Handbook of Dietary Fiber, Marcel Dekker, Inc., New York, 1987, pp. 1-468.

2) B. O. Schneeman: Soluble vs insoluble fiber-Different physiological responses. Food Technal., 41 (2), 81-82 (1987).

3) A. Keys, F. Grande, and J. T. Anderson: Fiber and pectin in the diet and serum cholesterol concentration in man. Proc. Soc. Exp. Biol. Med., 106, 555-558 (1961)

4) S. Reiser: Metabolic effects of dietary pectins related to human health. Food Technol., 41 (2), 91-99 (1987).

5) K. Tsuji, S. Oshima, E. Matsuzaki, A. Nakamura, S. Innami, T. Tezuka, and S. Suzuki: Effect of polysaccharides on 
cholesterol metabolistn (part 1). Studies on Konnyaku powder, sodium alginate, and pectin. Elyogaku Zassh, 26, 113-122 (1968) (in Japanese with English abstract).

6) K. Ito and Y. Tsuchiya: The effect of algal polysaccharides on the depressing of plasma cholesterol levels in rats, in "Proceeding of the Seventh International Seaweed Symposium" (ed. by K. Nishizawa), University of Tokyo Press, Tokyo, 1972, pp. 558-561.

7) K. Tsuji, E. Tsuji, and S. Suzuki: Effect of polysaccharides on cholesterol metabolism (part 3). Effect of several polysaccharides on serum cholesterol levels in cholesterol-fed rats. Eiyogaku Zassht, 32, 155-160 (1974) (in Japanese with English abstract).

8) E. Tsuji, K. Tsuji, and S. Suzuki: Effect of polysaccharides on cholesterol metabolism (part 6). Effect of various polysaccharides on serum and liver cholesterol levels in cholesterolfed rats. Eiyogaku Zasshi, 33, 273-281 (1975) (in Japanese with English abstract).

9) K. Tsuji, E. Tsuji, and S. Suzuki: Comparative cholesterollowering activities of various kinds of propylene glycol alginate. Eiyo to shokuryo, 31, 485-489 (1978) (in Japanese with English abstract).

10) A. F. Wells and B. H. Ershoff: Benerficial effects of pectin in prevention of hypercholesterolemia and increase in liver cholesterol in cholesterol-fed rats. J. Nutr, 74, 87-92 (1961).

11) S. Kiriyama, Y. Okazaki, and A. Yoshida: Hypocholesterolemic effect of polysaccharides and polysaccharide-rich foodstuffs in cholesterol-fed rats. J. Nutr., 97, 382-388 (1969)

12) American Institute of Nutrition: Report of the American Institute of Nutrition and hoc committee on standards for nutritional studies. J. Nutr., 107, 1340-1348 (1977).

13) A. Haug, B. Larsen, and O. Smidsrod: Uronic acid sequence in alginate from different sources. Carbohydr. Res., 32, 217 225 (1974).
14) Y. Nakagawa, K. Tsuji, H. Iwao, E. Tsuji, and S. Suzuki: Studies on dietray sucrose and cholesterol metabolism. Part 3. Effect of sucrose diet on serum high density lipoprotein cholesterol, fecal excretion of neutral sterols in cholesterolfed rats. Eiyogaku Zasshi, 39, 115-121 (1981) (in Japanese with English abstract).

15) E. G. Bligh and W. J. Dyer: A rapid method of total lipide extraction and purification. Can. J. Biochem. Physiol., 37, 911-917 (1959).

16) S. Aoe, F. Ota, and Y. Ayano: Effect of rice bran hemicellulose on the cholesterol metabolism in rats. Nippon Elyo Shokuryo Gakkaishl, 42, 55-61 (1989) (in Japanese with English abstract).

17) K. Tsuji and $X$. Nakagawa: Effects of simultaneous feeding of konjac mannan and cellulose on the growth, organ weight and lipid levels in hypercholesterolemic rats. Nucr. Rep. Int., 30, 19-25 (1984).

18) S. Ikegami, F. Tsuchihashi, H. Harada, N. Tsuchihashi, E. Nishide, and S. Innami: Effect of viscous indigestible polysaccharides on pancreatic-bilinary secretion and digestive organs in rats. J. Nutr, 120, 353-360 (1990).

19) Y. Tanimoto: Jikken Dobutsu no Ketsueki Nyo Seikagaku (Biochemistry of Blood and Urine of Test Animals), Soft Science, Tokyo, 1988, pp. 59-61 (in Japanese).

20) N. Takeuchi: Regulation mechanism of cholesterol metabolism. Eiyo to Shokuryo, 31, 439-448 (1978) (in Japanese).

21) M. Koseki, K. Tsuji, M. Kazama, N. Kitabatake, and E. Doi: Interaction between dietary cholesterol or fatty acids and water-soluble fibers and increase in cholesterol excreation by pectin in rats. Nlppon Shokuhin Kogyo Gakkaishi, 37, 559-564 (1990).

22) T. A. Miettinen and S. Tarpila: Serum lipids and cholesterol metabolism during guar gum, plantago ovata and high fibre treatment. Clin. Chem. Acta, 183, 253-262 (1989). 